\title{
ACTA RHEUMATOLOGICA
}

THE "Ligue Internationale contre le Rhumatisme," with which the Empire Rheumatism Campaign is affiliated, has been compelled to suspend its activities for the duration of the war and its journal, Acta Rheumatologica, suspended publication in December, 1939. The Empire Rheumatism Council has offered to publish from time to time in the AnNaLs news and announcements which would otherwise have appeared in the Acta, and the Editors will be glad to receive communications, and to publish them as far as space will permit. A list of recent publications and articles from the medical journals of many countries on the subject of rheumatism has been received from Dr. van Breemen and will be included in an early issue of the ANnals.

The Seventh International Congress on Rheumatic Diseases was to have taken place under the auspices of the League in America in June, 1940, but has had to be postponed. The President elect, Dr. Ralph Pemberton of Philadelphia, has circulated a pamphlet among the members explaining the postponement and giving an account of the programme which had been prepared, and with it a letter from which the following extracts have been taken:

"Certain misapprehensions seem to have arisen regarding the present status of the League. It is therefore deemed important for me, as President of the League, to state that I have never, in this official capacity, approved of any action which would create the impression that the League was dissolved, nor could $I$ in my capacity as President take any step, without the collaboration of the membership as a whole, which might result in the dissolution of the League.

"It is morally certain that if the League were to be dissolved an attempt would be made sooner or later upon cessation of hostilities to recreate it. . . . It is therefore believed by many in the United States that the creative efforts of Dr. van Breemen over the years, which have resulted in the League and the successful meetings held by it, should not be allowed to lapse. Furthermore, it seems of the highest importance in the present state of world affairs that every line of affiliation and co-operation should be kept available for use at the earliest moment. . . . It is the opinion of the American Rheumatism Association that the present structure and personnel of the League should be maintained, in a condition of suspended animation if necessary, for the duration of the war, ready to resume activities as soon as circumstances permit."

The Empire Rheumatism Council hope that by providing space in the ANNALs for news of the League it may be of service in promoting the objects advanced by Dr. Pemberton on behalf of his colleagues in America. 